\title{
Constatação de Bipolaris bicolor em plantas de açaizeiro no Brasil
}

\author{
Luiz Sebastião Poltronieri ${ }^{1}$; Jaqueline Rosemeire Verzignassi²; Rosemary Corrêa da Costa ${ }^{1}$
}

${ }^{1}$ Embrapa Amazônia Oriental, Tv. Enéas Pinheiro, S/N, CEP 66095-100, Belém, PA. ${ }^{2}$ Embrapa Gado de Corte, Av. Rádio Maia, , CEP 79002970, Campo Grande, MS.

Autor para correspondência: Jaqueline Rosemeire Verzignassi (jaqueline.verzignassi@embrapa.br)

Data de chegada: 19/01/2012. Aceito para publicação em: 13/04/2013.

O açaí (Euterpe oleracea Mart.) é uma palmeira típica da Região Amazônica e o Estado do Pará é o principal centro de dispersão natural dessa Arecácea. É na região do estuário do rio Amazonas que se encontram as maiores e mais densas populações naturais dessa palmeira, adaptada às condições elevadas de temperatura, precipitação pluviométrica e umidade relativa do ar. Como floresce e frutifica o ano todo, é possível encontrar, na mesma árvore, desde flores até frutos maduros. Seu consumo é feito in natura, em sucos, doces e sorvetes, entre várias outras formas. Durante visita realizada em áreas de cultivo comercial de açaí nos municípios de Belém e Ananindeua, no Pará, e em amostras recebidas de produtores de Frutal (MG), foram observadas manchas foliares em mudas com aproximadamente um ano de idade. Os sintomas consistiam de grande quantidade de lesões, bem definidas e dispersas pelo limbo foliar, com forma variando de circular a elipsóide, de coloração parda clara e bordos pardos escuros, e cobrindo acima de $50 \%$ da área foliar das plantas (Figura 1). Amostras de folhas foram coletadas e encaminhadas ao Laboratório de Fitopatologia da Embrapa Amazônia Oriental para a diagnose do agente causal da doença. O isolamento do agente etiológico foi efetuado a partir de pequenas porções de

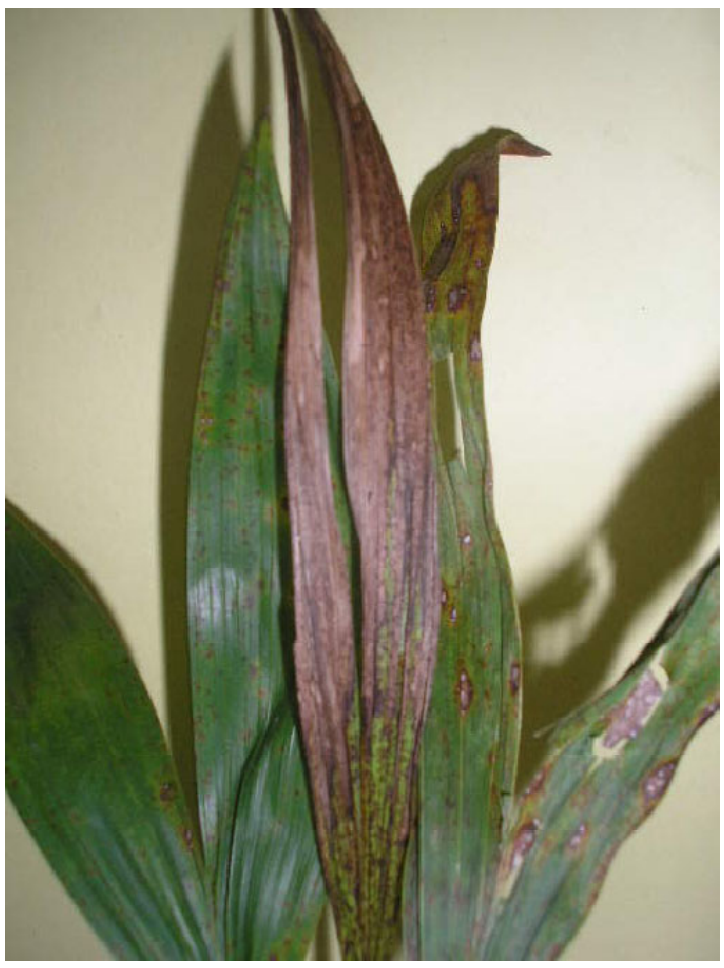

Figura 1. Folíolos de açaizeiro apresentando sintomas de mancha foliar de Bipolaris bicolor. Foto: Luiz S. Poltronieri.

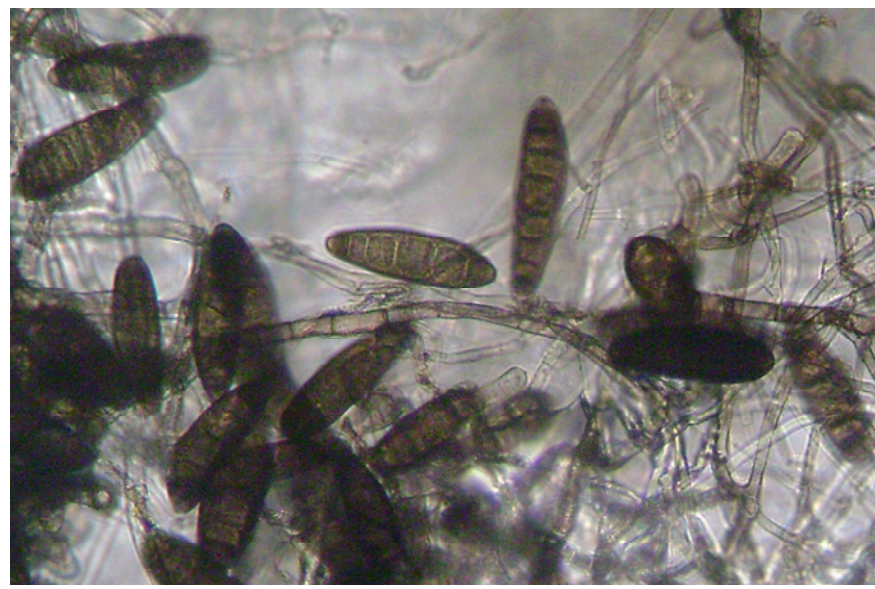

Figura 2. Conídios e conidióforos do fungo Bipolaris bicolor. Foto: Raimundo Nonato Batista da Silva.

tecidos lesionados desinfestados em hipoclorito de sódio $(2 \%, 2$ minutos), lavados em água destilada e transferidos para placas de Petri contendo ágar-água ( $2 \%)$. As placas foram mantidas por três dias à $26^{\circ} \mathrm{C}$, sob luz fluorescente e fotoperíodo de 12 horas. A partir de então, verificou-se a presença de colônias fúngicas e procedeu-se a multiplicação dos isolados obtidos em placas contendo meio de cultura BDA, mantidas nas condições anteriormente citadas. Após quatro dias de plaqueamento e a partir da observação de lâminas ao microscópio óptico, preparadas a partir do isolado (Figura 2), verificou-se tratar de Bipolaris sp. (BARNETT, H.L.; HUNTER, B.B. Illustrated genera of imperfect fungi. 4 ed. St. Paul: APS Press. 1998. 218p). Culturas provenientes do isolado foram enviadas ao Dr. Paul Kirk (CABI Bioscience, Reino Unido), que identificou o fungo como pertencente à espécie Bipolaris bicolor (Mitra) Shoemaker (teleomorfo Cochliobolus bicolor Paul \& Parbery) sin: Drechslera bicolor (Mitra) Subramanianet Jain, Helmintosporium bicolor Mitra. Teleomorfo: Cochliobolus bicolor Paul \& Parbery. O referido fungo apresenta conídios retos ou raramente curvos, cilíndricos ou largos no centro e afilado nas extremidades (2,88-7,68 $\mathrm{mm} \mathrm{X} \mathrm{1,44-2,4} \mathrm{mm})$; conidióforos simples, isolados ou em pequenos grupos retos ou flexuosos e septados. Para confirmar a patogenicidade desse isolado, folhas sadias destacadas de E. oleracea, previamente feridas, foram inoculadas com discos de micélio + meio de cultura BDA, com seis dias de idade. Folhas sadias também foram submetidas a ferimento e esses foram cobertos por discos de ágarágua, servindo como testemunha. As folhas foram submetidas à câmara úmida por $48 \mathrm{~h}$, sendo mantidas em bandejas cobertas com sacos plásticos em condições de laboratório. Após cinco dias, as folhas reproduziram os mesmos sintomas encontrados no campo e 
o reisolamento de $B$. bicolor confirmou a patogenicidade do isolado como agente causal das manchas foliares do açaí. Bipolaris bicolor foi relatado pela primeira vez no Brasil causando lesões foliares em pupunheira (Bactris gasipaes Kunth) no Espírito Santo (Morejón, K.R.; Kimati, H. \& Fancelli, I. Bipolaris bicolor (Mitra) Shoemaker: Espécie associada a manchas foliares de la palm pupunha (Bactris gasipaes Kunth) em Brasil. Rev Iberoam Micol., 15:55-57, 1998). Ressalta-se que
Exserohilum rostratum (anamorfo de Setosphaeria rostrata) também foi encontrado causando manchas foliares em açaizeiro no Brasil (Poltronieri, L.S.; Verzignassi, J.R.; Benchimol, R.L. \& Freire, F.C.O. Primeiro registro de Exserohilum rostratum (anamorfo de Setosphaeria rostrata) causando manchas foliares em açaizeiro no Brasil. Summa Phytopathol., 34(2):195, 2008), no entanto, este é o primeiro relato de Bipolaris bicolor causando manchas foliares em açaizeiro no Brasil. 